\title{
A Reliable and Rapid Multiplex RT-PCR Assay for Detection of Two Potyviruses and a Pararetrovirus Infecting Canna Plants
}

\author{
Ravendra P. Chauhan, Dulanjani Wijayasekara, Mark A. Webb, and Jeanmarie Verchot, Department of Entomology and Plant
} Pathology, Oklahoma State University, Stillwater 74078

\begin{abstract}
Chauhan, R. P., Wijayasekara, D., Webb, M. A., and Verchot, J. 2015. A reliable and rapid multiplex RT-PCR assay for detection of two potyviruses and a pararetrovirus infecting canna plants. Plant Dis. 99:1695-1703.

Canna plants are subject to serious virus diseases. The three most common viruses identified in canna plants are Bean yellow mosaic virus, Canna yellow mottle virus, and Canna yellow streak virus. Recent studies indicate that canna plants are commonly infected with more than one virus. Thus, the efficient control of these viruses in canna plants requires the availability of a reliable method for detecting mixed virus infection. This report presents a two-step multiplex reverse-transcription polymerase chain reaction (RT-PCR) that was developed to simultaneously detect

two potyviruses and one pararetrovirus genome. We optimized the method for nucleic acid isolation for managing a large population of samples, and the primer concentrations to ensure sensitivity and reliability of the assay, and determined the detection limit in simplex and multiplex RT-PCR assays using plasmid controls and nucleic acids isolated from virus-infected plants. Combined with an automated method for total nucleic acid isolation, this multiplex RT-PCR procedure could be routinely used for virus detection in research and diagnostic laboratories.
\end{abstract}

Canna plants (Canna $\times$ generalis) are among the most popular landscape plants that are traded globally and sold at major retailers and nurseries (Cooke 2001; Maas-Van De Kamer and Maas 2008). Because canna plants are grown from rhizomes and vegetatively propagated, once a virus is established in plants, the pathogen could be perpetuated for several generations. Therefore, germplasm screening to identify healthy stocks and propagation of only healthy stocks are vital to sustain the industry. Until now, there have not been commercially available assays to help growers identify virus-infected plants and segregate them from the healthy planting stocks.

Canna yellow streak virus (CaYSV) is a potyvirus that was reported in 2007 in the United Kingdom (Monger et al. 2007), after which it became known as a problem in canna production in many countries. CaYSV has a positive-strand RNA genome, and the entire genome sequence was first reported in 2010 (Monger et al. 2010). A more recent study reported the sequences for nine isolates of CaYSV and demonstrated that CaYSV belongs to the Sugarcane mosaic virus subgroup of potyviruses, with Johnsongrass mosaic virus as the closest relative (Chauhan et al. 2015). Currently, there are no commercial serological or reverse-transcription polymerase chain reaction (RTPCR) methods for identification. Canna yellow mottle virus (CaYMV) was first reported in 1985 to be a bacilliform virus infecting canna plants in Japan and then was reported in 1988 in the United States (Lockhart 1988). Approximately 565 bp of the DNA genome has been reported in GenBank, which shares homology with members of the Badnavirus genus of Caulimoviridae, and we previously reported a PCR assay for CaYMV detection (Rajakaruna et al. 2014). Bean yellow mosaic virus (BYMV) is another potyvirus which is widely known, and there are commercial serological tests for its detection. A recent survey of 24 canna varieties (more than 900 plants) found that more than $50 \%$ of plants grown from rhizomes were infected with BYMV, CaYMV, or CaYSV (Rajakaruna et al. 2014). In fact, isolation of CaYSV included prescreening plants and excluding ones that test positive for BYMV (Chauhan et al. 2015). These

Corresponding author: J. Verchot; E-mail: Verchot.lubicz@okstate.edu

Accepted for publication 12 June 2015.

http://dx.doi.org/10.1094/PDIS-02-15-0225-RE

(C) 2015 The American Phytopathological Society three viruses cause great concern for growers because their spread is likely to follow global trade of rhizomes. Although simplex detection of CaYSV, CaYMV, and BYMV could be carried out routinely (Chauhan et al. 2015; Rajakaruna et al. 2014), a single multiplex RT-PCR diagnostic test to identify each of these viruses in infected materials would aid the industry to select for clean planting stocks and facilitate the global trade of clean rhizomes.

RT-PCR is popular method for practical diagnosis of potyviruses and badnaviruses. Multiplex RT-PCR has been used to detect transcripts of Rice tungro bacilliform virus (a badnavirus), which has a DNA genome, and Rice tungro spherical virus (a waikavirus), which has an RNA genome (Periasamy et al. 2006). The use of RT-PCR provides rapid and sensitive detection of most viruses. In this study, we developed a highly sensitive and reliable multiplex RT-PCR method for simultaneous detection of BYMV, CaYMV, and CaYSV in canna leaves. This method uses total nucleic acid (TNA) extracts, which provides the opportunity for primers to amplify a product from either CaYMV genomic DNA or transcripts. Detection of both RNA and DNA virus genomes by multiplex RT-PCR requires high-quality, clean, and concentrated genetic material. The badnavirus genome can exist as a circular double-stranded DNA genome and as genome-integrated badnavirus sequences which can also give rise to disease (Gayral and Iskra-Caruana 2009; Gayral et al. 2008; Harper et al. 1999a,b). The challenge for detecting CaYMV is that no one has yet reported isolating the virus genome from canna leaves, suggesting that a protocol is needed for DNA extraction from canna leaves that recovers intact, concentrated episomal DNA (replicating form) alongside the plant genomic DNA. On the other hand, the RNA genomes of potyviruses are less stable than DNA and are subject to hydrolysis by plant endogenous RNAses that might be released during extraction. In addition, canna leaves contain quantities of polysaccharides, phenolic and fibrous tissues that are difficult to remove. Thus, the challenge is to consistently recover TNA from plants that contain both high-quality RNA for RT, needed for PCR detection of potyviruses and badnavirus RNA, as well as high-quality DNA for direct PCR detection of CaYMV. In addition, such a protocol needs to be scalable for greenhouse screening and population studies.

There are a large number of plant-specific protocols available for extraction of RNA or DNA from leaves (Chang et al. 1993; Gambino et al. 2008; Kalinowska et al. 2012; Slater 1988). For extraction of plant RNA and DNA virus genomes, modifications of Trizol-based 
or cetyltrimethylammonium bromide-based methods have been employed (Ge et al. 2013; Portillo et al. 2006). Otherwise, researchers typically rely on kits, the most popular of which are the Qiagen DNeasy or RNeasy kits (Kalinowska et al. 2012; Li et al. 2008; Pervaiz et al. 2011). Given that canna hybrids can have burgundy, green, variegated, or red- and green-colored leaves we needed to identify a method for TNA extraction that would be effective across canna varieties, regardless of the pigments and phenolics that are in the leaves. We present here both a reliable and partially automated workflow for TNA extraction and multiplex RT-PCR detection of BYMV, CaYSV, and CaYMV that could be applied in a greenhouse germplasm-screening program.

\section{Materials and Methods}

Sampling. Two leaf punches weighing $70 \mathrm{mg}$ combined were collected in presterilized XXtuff reinforced microvials containing 2.0-mm zirconia beads (Biospec Products) and frozen immediately in liquid nitrogen. Preserved tissues are stored for a short period of time (between 1 day and 2 weeks) at $-80^{\circ} \mathrm{C}$.

Extraction of RNA and TNA. Adequate grinding is critical to obtain high yields of genetic material. Extraction of RNA and TNA were carried out using the Maxwell 16 LEV SimplyRNA Tissue Kit (Promega Corp.). Samples were taken from the $-80^{\circ} \mathrm{C}$ freezer and placed on ice. Then, $200 \mu$ l of chilled 1-thioglycerol/homogenization solution provided in the kit was added to each sample. Next, tubes were loaded into the BeadBug microtube homogenizer (Benchmark Scientific) and grinding was carried out at $16,000 \times g$ for $2 \mathrm{~min}$. Ground samples were centrifuged at $16,000 \times g$ for $5 \mathrm{~min}$. The supernatant $(200 \mu \mathrm{l})$ was transferred to an Eppendorf tube and $200 \mu \mathrm{l}$ of lysis buffer was added. Samples were vortexed, after which $400 \mu l$ of the lysate was transferred to the Maxwell 16 LEV cartridge for processing in the Maxwell robot. To recover TNA, the DNAse I solution provided by the manufacturer to prepare RNA was left out of the protocol. Elution was carried out using prechilled nuclease-free water.

TRIZOL and TRI Reagent were also used to extract intact RNA from $70 \mathrm{mg}$ of tissue. TRIZOL or TRI Reagent $(1 \mathrm{ml})$ was added to ground tissue and incubated at room temperature for $5 \mathrm{~min}$. Chloroform $(200 \mu \mathrm{l})$ was added and samples were mixed briefly, then incubated at room temperature for $15 \mathrm{~min}$. Next, samples were centrifuged at $16,000 \times g$ for $15 \mathrm{~min}$ at $4^{\circ} \mathrm{C}$. The aqueous phase was recovered and RNA was precipitated using isopropanol. RNA was pelleted by centrifugation and then resuspended in nuclease-free water.

RNA and TNA were examined using laboratory standard $1 \%$ agarose gel electrophoresis or $1 \%$ agarose/formaldehyde gel electrophoresis. Gels were stained with ethidium bromide and photographed.

Quantification of RNA and TNA. The NanoDrop ND-1000 (Thermo Fisher Scientific) was used to check the quality and yield of TNA, with an expectation of a 260/280 value of at least 1.9 optical density. To quantify TNA, the extinction coefficient for DNA was used. Agilent 2100 Bioanalyzer (Applied Biosystems) was used to quantify plasmid DNA and TNA. The samples were analyzed by $1 \%$ agarose gel electrophoresis using ethidium bromide staining.

Control plasmids. pBYMV382 contains a 382-bp fragment of the BYMV coat protein (nucleotide position 8,949 to 9,329) inserted into pGEM-T Easy vector. pYM-036P1 contains a 1,356-bp fragment of the CaYMV genome inserted into pGEM-T Easy vector (Fig. 1). pYSOK7672 contains a 3' 1,827-bp fragment of CaYSV genome (OK isolate) which extends from nucleotide position 7,672 to 9,502, inserted into the pCR2.1 vector. Plasmids were reported previously (Chauhan et al. 2015; Rajakaruna et al. 2014).

RT and multiplex PCR. RT was carried out using the HighCapacity DNA Reverse Transcription kit (Applied Biosystems), random primers, and $500 \mathrm{ng}$ of TNA, according to the manufacturer's protocol. The final cDNA concentration was determined using the NanoDrop ND-1000 spectrophotometer. PCR was performed using approximately $2 \mu \mathrm{g}$ of cDNA (a final reaction concentration of $80 \mathrm{ng} / \mu \mathrm{l}$ ) and GoTaq Flexi DNA polymerase (Promega Corp.) in $20-\mu 1$ reactions. The thermal cycling conditions were one cycle at $95^{\circ} \mathrm{C}$ for $2 \mathrm{~min} ; 25$ cycles at $95^{\circ} \mathrm{C}$ for $45 \mathrm{~s}, 52^{\circ} \mathrm{C}$ for $45 \mathrm{~s}$, and $72^{\circ} \mathrm{C}$ for $45 \mathrm{~s}$; followed by a final extension at $72^{\circ} \mathrm{C}$ for $7 \mathrm{~min}$. Direct PCR of plasmids was carried out using the same thermal cycling conditions. Multiplex PCR was carried out using primers that are depicted in Figure 1 and Table 1 (Rajakaruna et al. 2014). The resulting amplicons of 382, 565, and 695 bp correspond to BYMV, CaYMV, and CaYSV genomes, respectively.

\section{Results}

Results of RNA extraction using Maxwell, TRIZOL, and TRI Reagent. To achieve an automated and highly reliable
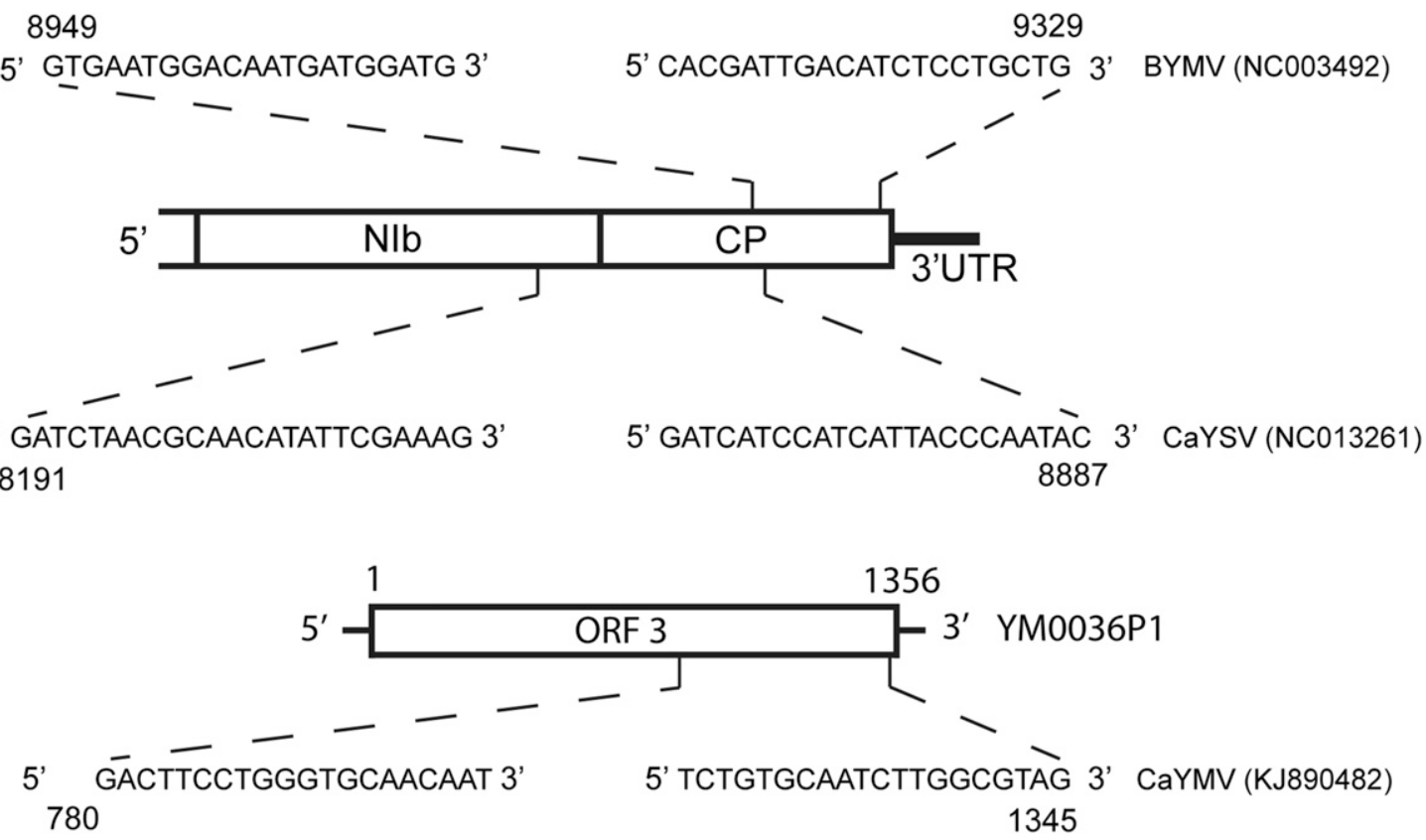

Fig. 1. Diagrammatic representation of polymerase chain reaction (PCR) primers and their locations in the respective viral genomes. Bean yellow mosaic virus (BYMV) and Canna yellow streak virus (CaYSV) are both potyviruses and the CaYSV PCR primers overlap the NIb and coat protein (CP) coding regions while the BYMV primers both reside in the CP coding regions of the respective viral genomes. A fragment of open reading frame (ORF) 3 of Canna yellow mottle virus (CaYMV) is maintained in plasmid YM0036P1. Nucleotide positions of the PCR primers within the ORF 3 coding region are identified. 
multiplex RT-PCR assay that detects potyvirus and badnavirus transcripts as well as badnaviral genomic DNA, we needed to obtain a high yield of plant TNA that would capture a broad range of nucleic acid species. High-yield and pure TNA was obtained from three different hybrid canna cultivars that have variegated, red, or green leaves (Table 2). The best yields and quality were obtained using $70 \mathrm{mg}$ of starting tissue and the Maxwell robot to obtain sufficient total nucleic acids for downstream operations. Using the Maxwell 16 LEV SimplyRNA Tissue Kit, the average RNA obtained from the variegated leaves of 'Striped Beauty' was $137.15 \mathrm{ng} / \mu \mathrm{l}$. The average RNA yield from the burgundy leaves of 'Australia' was $172.74 \mathrm{ng} / \mu \mathrm{l}$ (Table 2). RNA isolated using TRIZOL or TRI Reagent from the same varieties produced wider ranging yields that were as low as $30 \mathrm{ng} / \mu \mathrm{l}$ and as high as $214 \mathrm{ng} / \mu \mathrm{l}$ (Table 2). It is important to note that the average 260/280 ratio values using the Maxwell Robot were 1.98 to 2.09 whereas the values using TRIZOL and TRI Reagent were 1.66 to 1.74 (Table 2). The higher ratio indicates improved purity. Regarding RNA integrity, the Maxwell kit maintained intact RNA as inferred from the 2:1 proportion of $28 \mathrm{~S}$ to $18 \mathrm{~S}$ ribosomal RNA (rRNA) seen by agarose gel electrophoresis (Fig. 2A). Low molecular weight smears were observed by agarose gel electrophoresis for RNA samples extracted using TRIZOL or TRI Reagent, indicating that the RNA is not intact (Fig. 2A). These data suggest that RNA yields and purity were more consistent and reliable using the Maxwell kit than the TRIZOL or TRI Reagent.

The next step was to modify the Maxwell kit isolation procedure to isolate TNA for the purpose of multiplex PCR based detection of BYMV, CaYSV, and CaYMV. For this, the DNase I was left out of the extraction procedure. The quality of the preparation was judged by the appearance of a significant population of major RNA species, including the cytosolic 28S, 8S RNA, and 5S/tRNA, as well as the chloroplast and mitochondrial 23S and 16S RNA (Kondo et al. 2013; Orjuela et al. 2013). Notably, the yields and purity of TNA from canna leaves taken from three varieties (Striped Beauty, Australia, and 'President') were consistently above $100 \mathrm{ng} / \mu \mathrm{l}$ and, in some cases, greater than $300 \mathrm{ng} / \mu \mathrm{l}$. The average $260 / 280$ ratio was 1.99 or greater (Table 2). Samples were examined by agarose gel electrophoresis and the quality of DNA and RNA in each extract appeared to be consistent and satisfactory. One significant DNA species appeared at the top of the gel, just above the ladder, and several significant RNA species beyond the 28S, 18S, and 5S RNA (Kondo et al. 2013; Orjuela et al. 2013). The DNA appeared to be intact and the proportion of genomic DNA relative to RNA across samples was consistent (Fig. 2B).

The Agilent 2100 Bioanalyzer was used to characterize the quality of RNA in both the total RNA and TNA preparations obtained using the Maxwell kit (Fig. 2C). The electropherogram revealed the distinct rRNA peaks corresponding to cytosolic 28S, 18S, and 5S/tRNA species in the total RNA preparations (Fig. 2C, lanes 1 and 2). In the TNA preparations, there are additional peaks corresponding to the $23 \mathrm{~S}$ and $16 \mathrm{~S}$ RNA belonging to the chloroplast and mitochondria. The heights of these peaks is well above the baseline. Although a quality RNA preparation is typically judged by a $28 \mathrm{~S} / 18 \mathrm{~S}$ ratio that is 2 or larger, it is also noteworthy that the abundance of the 5S RNA species was comparable between preparations. Typically, tRNA is not removed by RNA extraction and might appear as low molecular weight RNA that migrate alongside the 5S RNA species (Orjuela et al. 2013). The 5S/tRNA peak seemed consistent among RNA and TNA preparations.

To determine whether the quality of DNA recovered using the modified TNA preparation was comparable or better than one alternative method of DNA isolation, we chose to use the Qiagen DNeasy Plant Mini kit for comparison (Fig. 2D). We isolated samples from the same plant, ran them on a gel, and used the Agilent 2100 Bioanalyer to characterize the quality of the DNA in both preparations. The agarose gel showed distinct bands above $10 \mathrm{~kb}$ representing genomic DNA in both preparations but the DNA isolated using the Qiagen kit was smeared in the gel lane (Fig. 2D). The electropherogram revealed distinct genomic DNA peaks in both preparations but a bubble of degraded DNA existed below this peak in the sample prepared using the Qiagen kit. These data reveal that the DNA in the TNA preparation is of a superior quality.

Optimization of primers and PCR conditions that are compatible with multiplex reaction. A reliable multiplex RT-PCR method that successfully detects BYMV, CaYMV, and CaYSV in canna leaves requires appropriate primers that are (i) compatible with a multiplex reaction, (ii) have similar melting temperatures, (iii) flank genomic regions of different sizes, and (iv) produce PCR product sizes that allow the discrimination of the different virus species by agarose gel electrophoresis. The RT-PCR assay must also be sensitive enough to detect picogram quantities of virus-related cDNA by gel electrophoresis.

Simplex PCR was carried out using pYSOK7672, pBYMV382, and pYM036P1 plasmids to determine whether the primers detected CaYSV, BYMV, and CaYMV sequences, respectively. The Agilent Bioanalyzer was used to quantify linearized plasmids, and dilutions from $100 \mathrm{ng} / \mu \mathrm{l}$

Table 1. Primers for virus detection and identification in canna plants

\begin{tabular}{llclc}
\hline Virus $^{\mathbf{a}}$ & Primer name & Amplicon size (bp) & \multicolumn{1}{c}{ Primer sequences $\left(\mathbf{5}^{\prime} \mathbf{-} \mathbf{3}^{\prime}\right)$} & Melting Temperature $\left({ }^{\circ} \mathbf{C}\right)$ \\
\hline CaYSV & Canna-F1 & 695 & GAT CTA ACG CAA CAT ATT CGA AAG & F: 52.2 \\
& Canna-R2 & $\ldots$ & GAT CAT CCA TCA TTA CCC AAT AC & R: 51.0 \\
CaYMV & CaYMV-3F & 565 & GAC TTC CTG GGT GCA ACA AT & F: 55.6 \\
& CaYMV-4R & $\ldots$ & TCT GTG CAA TCT TGG CGT AG & R: 55.2 \\
BYMV & BYMV-F & 382 & GTG AAT GGA CAA TGA TGG ATG & F: 51.6 \\
& BYMV-R & $\ldots$ & CAC GAT TGA CAT CTC CTG CTG & R: 55.8 \\
\hline
\end{tabular}

a Canna yellow streak virus (CaYSV), Canna yellow mottle virus (CaYMV), and Bean yellow mosaic virus (BYMV).

Table 2. Nucleic acids yielded from leaves using the Maxwell method

\begin{tabular}{|c|c|c|c|c|c|}
\hline Cultivar & Leaf color & Average yield $(\mathrm{ng} / \mu \mathrm{l})^{\mathrm{a}}$ & Range Yield & Average $260 / 280^{a}$ & Method \\
\hline \multicolumn{6}{|l|}{ RNA isolation } \\
\hline \multirow[t]{2}{*}{ Striped Beauty } & Variegated & 137.15 & $91-179$ & 1.98 & Maxwell \\
\hline & $\ldots$ & 113.28 & $48-214$ & 1.66 & Trizol \\
\hline \multirow[t]{2}{*}{ Australia } & Burgundy & 172.74 & $144-183$ & 2.09 & Maxwell \\
\hline & $\ldots$ & 68.66 & $30.2-161$ & 1.74 & Tri Reagent \\
\hline \multicolumn{6}{|l|}{ TNA isolation } \\
\hline Striped Beauty & Variegated & 216.79 & $112-314.3$ & 2.17 & Maxwell \\
\hline Australia & Burgundy & 153.78 & $115-181$ & 1.99 & Maxwell \\
\hline President & Green & 321.50 & $202-380$ & 2.11 & Maxwell \\
\hline
\end{tabular}

a Averages for three plant varieties. Five to eight samples were tested for each variety.

a Total nucleic acid (TNA) isolation (DNA and RNA). 
to $1 \mathrm{pg} / \mu \mathrm{l}$ were prepared using nuclease-free water. Direct PCR was carried out using green and colorless GoTaq with $2.5 \mathrm{mM} \mathrm{MgCl}_{2}$ (Fig. 3A). The designed PCR primers detected virus sequences in reactions containing a final concentration of plasmid DNA of $5 \mathrm{ng} / \mu \mathrm{l}, 0.5 \mathrm{ng} / \mu \mathrm{l}, 0.05 \mathrm{ng} / \mu \mathrm{l}$, $5 \mathrm{pg} / \mu \mathrm{l}, 0.5 \mathrm{pg} / \mu \mathrm{l}$, or $0.05 \mathrm{pg} / \mu \mathrm{l}$. The reaction products from reactions using green and colorless GoTaq were comparable. In addition, a set of PCR was carried out using added 7.5\% dimethyl sulfoxide (DMSO) (Gillet et al. 2013). The addition of DMSO to the reactions did not result in increased band intensities on the gel (Fig. 3A).

Then, $100 \mathrm{pg}, 1 \mathrm{pg}$, or $1 \mathrm{ng}$ of each pYSOK7672, pBYMV382, and pYM036P1 plasmid were combined and diluted in $100 \mathrm{ng}$ of TNA that was isolated from healthy plants to assess the sensitivity of PCR detection of virus sequences in a plant nucleic acid extract. In each reaction, three primer sets were combined, with a final concentration of $0.9 \mu \mathrm{M}$ (Fig. 3B). In general, bands representing BYMV were most abundant in all mixed template dilutions (Fig. $3 \mathrm{~B})$. These data suggest that the concentration ratio of primers might impede detection of all three viruses. The results using green and colorless GoTaq buffers after 25 cycles were similar, suggesting that the green dye did not affect the outcomes of multiplex PCR. PCR carried out using $7.5 \%$ DMSO in the reaction produced stronger bands detecting CaYMV and CaYSV than reactions lacking DMSO (Fig. $3 \mathrm{~B}$, lanes 4 to 6 and 11 to 13 ).
Various ratios of primers were tested to optimize detection of the three virus cDNAs (diluted in TNA extracted from healthy canna plants) in a multiplex reaction. PCR was carried out for 35 cycles using plasmid at $0.05 \mathrm{pg} / \mu 1$ along with 0.5 and $0.1 \mu \mathrm{M}$ BYMV forward and reverse primers (Fig. 3C). Interestingly, reducing the BYMVdetecting primers correlated with stronger bands corresponding to CaYSV and CaYMV PCR products. As little as $0.2 \mu \mathrm{M}$ BYMV primers is sufficient for RT-PCR amplification of BYMV sequences. Bands representing CaYMV-related PCR products were visible when 0.9 but not $0.5 \mu \mathrm{M}$ final concentrations of CaYMV primers were used (Fig. 3C). To further optimize primer concentrations, PCR was carried out using BYMV/CaYMV/CaYSV primers in the following concentration ratios: $0.1 / 0.9 / 0.9,0.1 / 0.5 / 0.9,0.2 / 0.9 / 0.9$, and $0.5 / 0.9 / 0.9 \mu \mathrm{M}$ (Fig. 3D). Following gel electrophoresis of PCR products, three bands were most often detected using the ration 0.2/0.9/0.9 $\mu \mathrm{M}$ BYMV/CaYMV/CaYSV primers.

Then to determine whether this optimized multiplex PCR could detect viral cDNA in TNA extracted from healthy canna leaves, PCR amplification was carried out using, 7.5\% DMSO, $2.5 \mathrm{mM}$ $\mathrm{MgCl}_{2}$, an annealing temperature of $50^{\circ} \mathrm{C}$, and $1 \mathrm{pg}$ of pYSOK7672, YM036P1, and pBYMV382 plasmids diluted in 100 ng of TNA from healthy canna leaves. Reactions were carried out for 35 cycles using $0.1 / 0.9 / 0.9,0.1 / 0.5 / 0.9,0.2 / 0.9 / 0.9$, and $0.5 / 0.9 / 0.9 \mu \mathrm{M}$
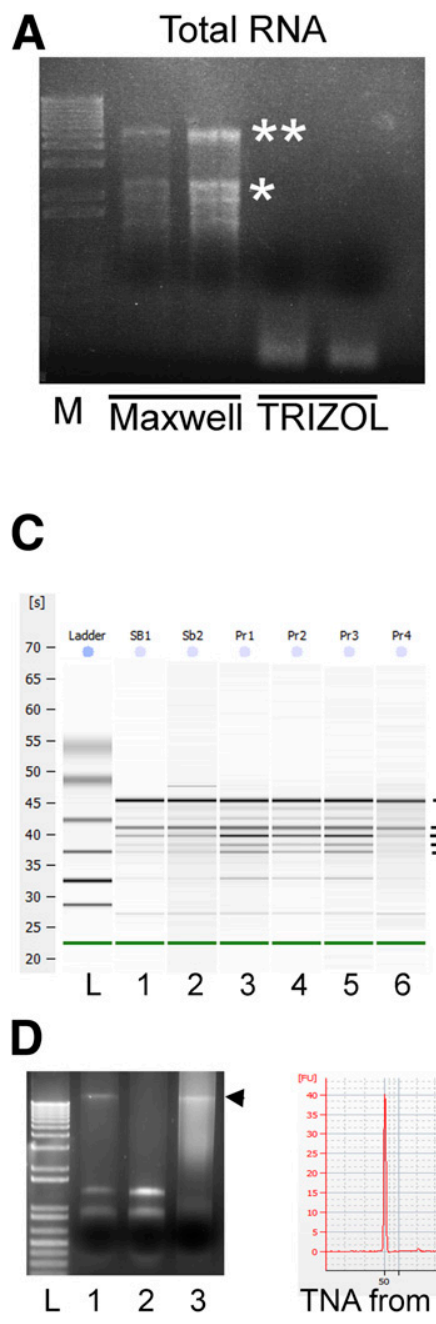

Fig. 2. Gel electrophoresis to examine nucleic acid integrity following extraction with Maxwell kit and TRIZOL. White or black arrowheads identify plant genomic DNA, ** identifies 28S RNA, and * identifies 18S RNA. A, Total RNA from two canna leaves ('Striped Beauty') were extracted by Maxwell and TRIZOL and run on a gel to compare RNA integrity. RNA species are intact following Maxwell kit isolation procedure but not TRIZOL isolation procedure. The $18 \mathrm{~S}$ and $28 \mathrm{~S}$ ribosomal RNA bands are clearly visible in the intact RNA. B, Total nucleic acid (TNA) from canna leaves. Canna varieties identified at the bottom of the gels. C, Electropherogram of RNA (lanes 1 and 2) and TNA (lanes 3 to 6 ). Lane M is the 1-kb ladder. Samples taken from two varieties identified on the right. The RNA integrity number (RIN) is automatically assigned to total RNA based on the entire electrophoretic trace of the RNA sample. D, Samples from a plant of 'Burning Ember'. Lanes 1 and 2 contain TNA and RNA, respectively, isolated using same Maxwell kit. Lane $3=$ DNA isolated using the Qiagen Plant DNeasy kit. Two electropherograms representing nucleic acids in lanes 1 and 3.
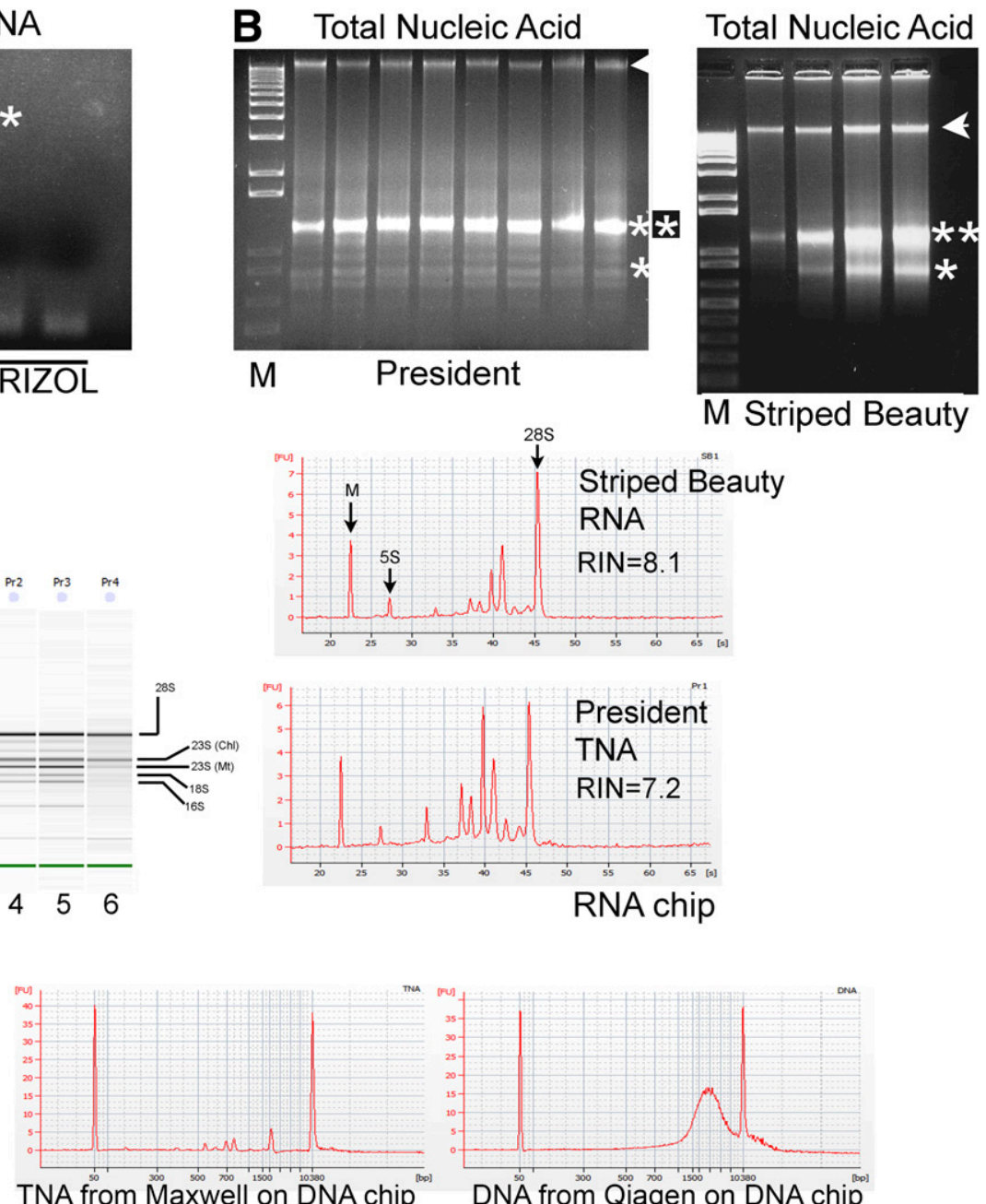

DNA from Qiagen on DNA chip 
BYMV/CaYMV/CaYSV primers (Fig. 3D). As expected, the $0.2 / 0.9 / 0.9 \mu \mathrm{M}$ ratio produced bands of similar intensity representing BYMV, CaYMV, and CaYSV (Fig. 3D, lane 3). Using the $0.1 / 0.9 / 0.9 \mu \mathrm{M}$ ratio of primers produced prominent bands representing CaYSV and CaYMV and a faint band detecting BYMV (Fig. 3D, lane 1). A ratio of $0.1 / 0.5 / 0.9 \mu \mathrm{M}$ produced two prominent bands representing CaYSV and BYMV (Fig. 3D, lane 2). When the $0.5 / 0.9 / 0.9 \mu \mathrm{M}$ ratio was used, the CaYSV cDNA was poorly detected, suggesting that the increase in BYMV primers diminished the ability to detect CaYSV cDNA in TNA extracts (Fig. 3D, lane 4).

To confirm that multiplex detection of viral cDNA is as sensitive as simplex detection of the same cDNA, PCR was carried out using progressively greater dilutions (in water) of linearized plasmids (Fig. 3E). Simplex and multiplex PCR were carried out for 35 cycles using a $0.2 / 0.9 / 0.9 \mu \mathrm{M}$ ratio of $\mathrm{BYMV} / \mathrm{CaYMV} / \mathrm{CaYSV}$ primers, $7.5 \%$ DMSO, $2.5 \mathrm{mM} \mathrm{MgCl}_{2}$, and $100 \mathrm{pg}$ (Fig. 3E, lanes 1, 5, 9, and 13), 10 pg (Fig. 3E, lanes 2, 6, 10, and 14), 1 pg (Fig. 3E, lanes 3, 7, 11, and 15), and $0.1 \mathrm{pg}$ (Fig. 3E, lanes 4, 8, 12, and 16) of pYSOK7672, pYM036P1, and pBYMV382 plasmids. Bands representing simplex and multiplex reaction products were observed

\section{A Singleplex, plasmid templates}

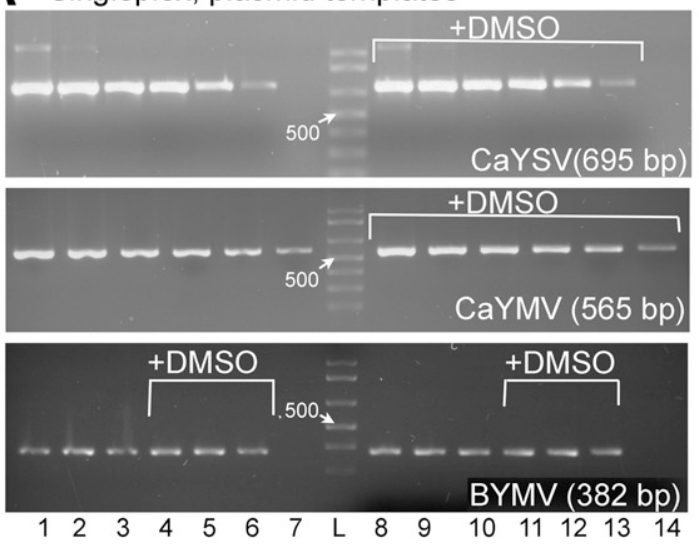

B $0.9 / 0.9 / 0.9 \mu \mathrm{M}$ primers

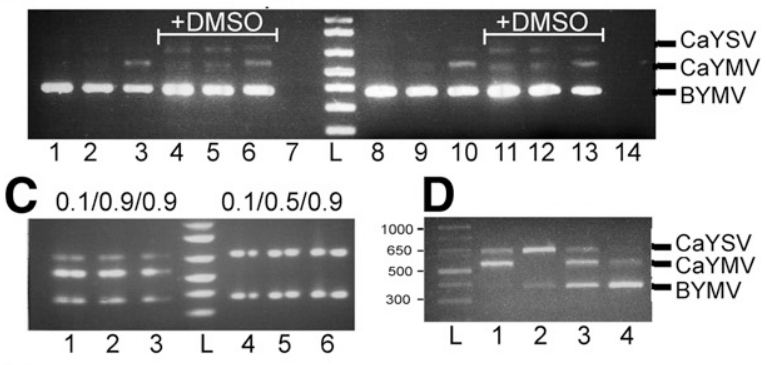

E

CaYSV CaYMV BYMV Multiplex 0

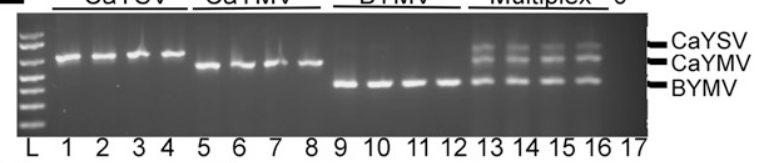

$\mathbf{F}$
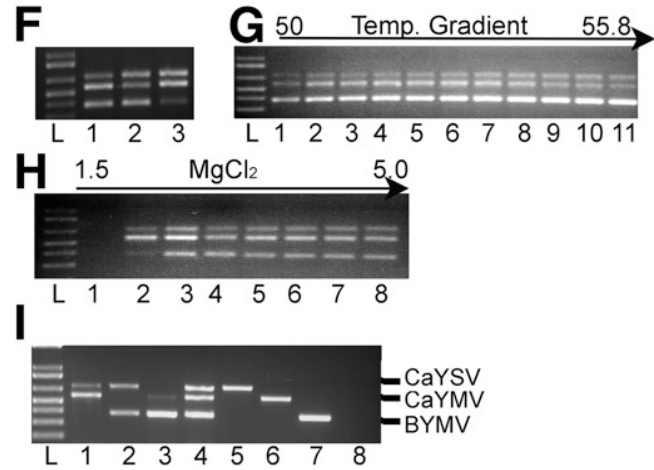

regardless of the template concentration, indicating that these primer combinations were adequate for detecting as little as $0.1 \mathrm{pg}$ of viral sequences by simplex and multiplex PCR (Fig. 3E). To further validate the sensitivity of these PCR conditions for detecting varying quantities of template, $10 \mathrm{pg}$ of two linearized plasmids was combined with $1 \mathrm{pg}$ of the third linearized plasmid and added to the reactions. The data demonstrated that limiting one template in the reaction did not hamper PCR detection of all three templates in the sample (Fig. 3F).

Having established that the primers are compatible for detecting viral cDNA in a multiplex reaction, temperature-gradient PCR was carried out to identify optimal annealing temperatures for multiplex PCR (Fig. 3G) using $1 \mathrm{ng}$ of mixture of plasmids diluted in water. Temperatures of 50 to $55.8^{\circ} \mathrm{C}$ produced comparable PCR products. There was not a profound difference in the outcomes within the temperature range tested; however, we selected $52^{\circ} \mathrm{C}$ as the annealing temperature for further work (Fig. 3G). The next step was to test varying $\mathrm{MgCl}_{2}$ concentrations (Fig. $3 \mathrm{H}$ ). The GoTaq buffer contains $1.5 \mathrm{mM} \mathrm{MgCl}_{2}$, and additional $\mathrm{MgCl}_{2}$ was added, raising the concentration to $2.0,2.5,3.0,3.5,4.0,4.5$, and $5.0 \mu \mathrm{M}$. The results indicate that a minimum of $2.5 \mu \mathrm{M} \mathrm{MgCl}_{2}$ is needed to detect all three bands in equal proportion, and that continuing to raise the $\mathrm{MgCl}_{2}$ concentration did not hamper the reaction outcomes (Fig. 3H).

In a final comparison (Fig. 3I), experiments were carried out to determine whether the primers cross-react with one of the other viral cDNAs introduced into the reaction. Varying combinations of plasmids (final concentration of $40 \mathrm{fg} / \mu \mathrm{l}$ ) were diluted in TNA extracted from healthy plants and all PCR were carried out using the cocktail of three primer sets. The appropriate PCR products were detected when pYSOK7672 was combined with either pYM036P1 or pBYMV382. Similarly, when pYMV036P1 and pBYMV382 were used, two PCR products of 382 and 565 bp were produced. When all three plasmids were combined, then three PCR products of 695 , 565 , and 382 bp were produced (Fig. 3I).

Fig. 3. To examine polymerase chain reaction (PCR) products obtained using plasmid templates, $2 \%$ agarose gel electrophoresis was used. A, Three gels containing simplex PCR products detecting Canna yellow streak virus (CaYSV), Canna yellow mottle virus (CaYMV), and Bean yellow mosaic virus (BYMV) sequences. Final concentrations of plasmid DNA of $5 \mathrm{ng} / \mu \mathrm{l}$ (lanes 1 and 8), $0.5 \mathrm{ng} / \mu \mathrm{l}$ (lanes 2 and 9), $0.05 \mathrm{ng} / \mu \mathrm{l}$ (lanes 3 and 10), $5 \mathrm{pg} / \mu \mathrm{l}$ (lanes 4 and 11), $0.5 \mathrm{pg} / \mu \mathrm{l}$ (lanes 5 and 12), and $0.05 \mathrm{pg} / \mu \mathrm{l}$ (lanes 5 and 13) were used. Lanes 7 and 14 were negative control reactions using water and no template DNA. DMSO = dimethyl sulfoxide. $\mathrm{B}$ to $\mathbf{E}$, Multiplex PCR carried out using a mixture of pYSOK7672, pYM036P1, and pBYMV382 plasmids. The respective concentrations of BYMV, CaYMV, and CaYSV primers, in this order, are provided above each panel. B, Lanes 7 and 14 are negative control reactions using water and no template DNA. C, PCR was carried out using 0.1/0.9/0.9 $\mu \mathrm{M}$ (lanes 1, 2, and 3) OR $0.1 / 0.5 / 0.9 \mu \mathrm{M}$ (lanes 4, 5 and 6) BYMV/CaYMV/CaYSV primers. D, Multiplex PCR products produced using plasmids diluted in total nucleic acid (TNA). Reactions were carried out using 0.1/0.9/0.9 $\mu \mathrm{M}$ (lane 1), 0.1/0.5/0.9 $\mu \mathrm{M}$ (lane 2), 0.2/0.9/0.9 $\mu \mathrm{M}$ (lane 3), and 0.5/0.9/0.9 $\mu \mathrm{M}$ (lane 4) BYMV/CaYMV/CaYSV primers. E, Simplex (lanes 1 to 12) and multiplex (lanes 13 to 16) detection using plasmids that were diluted 10-fold in each reaction. Multiplex PCR was carried out using all three plasmids in equal concentrations. Lanes 1, 5, 9, and 13 contain $100 \mathrm{pg}$ of plasmids; lanes 2, 6, 10, and 14 contain $10 \mathrm{pg}$ of plasmids; lanes $3,7,11$, and 15 contain $1 \mathrm{pg}$ of plasmids; and lanes 4 , 8,12 , and 16 contain $0.1 \mathrm{pg}$ of plasmids. F, Multiplex PCR was carried out using a constant level of $0.2 / 0.9 / 0.9 \mu \mathrm{M}$ BYMV/CaYMV/CaYSV primers. Lane 1: PCR contained 1/10/10 pg of pYSOK7672/ pYM036P1/pBYMV382 plasmids. Lane 2: PCR contained 10/1/10 pg of pYSOK7672/pYM036P1/ pBYMV382 plasmids. Lane 3: PCR contained 10/10/1 pg of pYSOK7672/pYM036P1/ pBYMV382 plasmids. G, Multiplex PCR carried out using $1 \mathrm{ng}$ of each plasmid template and $0.2 / 0.9 / 0.9 \mu \mathrm{M} \mathrm{BYMV} / \mathrm{CaYMV} / \mathrm{CaYSV}$ primers. Lane $1,50.0^{\circ} \mathrm{C}$; lane 2, $50.2^{\circ} \mathrm{C}$; Lane $3,50.6^{\circ} \mathrm{C}$; lane $4,51.2^{\circ} \mathrm{C}$; lane $5,51.9^{\circ} \mathrm{C}$; lane $6,52.6^{\circ} \mathrm{C}$; lane $7,53.4^{\circ} \mathrm{C}$; lane 8 , $54.1^{\circ} \mathrm{C}$; lane $9,54.8^{\circ} \mathrm{C}$; lane $10,55.4^{\circ} \mathrm{C}$; and lane $11,55.8^{\circ} \mathrm{C}$. H, Lanes 1 to 8 contain PCR products produced using $1.5,2,2.5,3,3.5,4,4.5$, and $5.0 \mathrm{mM} \mathrm{MgCl} 2$, respectively. I, Multiplex PCR carried out using the following combinations of plasmids diluted in TNA extracts: lane 1, pYSOK7672 and pYM0036P1; lane 2, pYSOK7672 and pBYMV382; lane 3, pYMV0036P1 and pBYMV382; lane 4, pYSOK7672, pYM0036P1, and pBYMV382; lane 5, pYSOK-7672; lane 6 pYM0036P1; lane 7 pBYMV382; and lane 8 no plasmid. In all panels, "L" refers to the 1-kb Plus DNA ladder. Base pair sizes for some marker DNA are identified next to the ladder reference in some panels. 
Use of diagnostic RT-PCR to detect viruses in hybrid canna varieties. Canna plants, belonging to two varieties named 'Tangelo' and Australia (green-leaved and burgundy-leaved, respectively) were grown in the greenhouse from rhizomes and the emerging leaves showed symptoms of virus infection. Green- and burgundy-leaved samples were selected to demonstrate that canna variety does not affect the PCR outcomes. TNA (approximately $500 \mathrm{ng}$ ) was isolated from symptomatic leaves and subjected to multiplex RT-PCR to identify virus sequences. The positive control included a mixture of pYSOK7672, pBYMV382, and pYM036P1 plasmids at a final reaction concentration of $40 \mathrm{fg} / \mu \mathrm{l}$. In all, 9 of 10 plants of Tangelo produced 695-bp PCR products, suggesting that these plants are infected with only CaYSV (Fig. 4A). Seven plants of Australia were also tested and five TNA samples produced only a 565-bp PCR product that corresponds to CaYMV. Two TNA samples produced two PCR products of 695 and $565 \mathrm{bp}$, which indicates that these two plants are coinfected with CaYSV and CaYMV (Fig. 4B). None of these plants tested positive for BYMV. A third set of TNA isolated from 10 plants of Tangelo was tested, and 8 were positive for BYMV, 2 were positive for CaYMV, and 1 was positive for CaYSV (Fig. 4C).

To demonstrate that the simplex and multiplex RT-PCR methods produce similar outcomes, a set of 30 TNA (approximately $500 \mathrm{ng}$ ) extracts from three canna varieties ('Black Knight', 'Burning Ember', and 'Tropical Sunrise') was subjected to simplex and multiplex PCR. Black Knight and Burning Ember are bronze-leaved varieties and Tropical Sunrise is a green-leaved variety. The results of simplex and multiplex RT-PCR were identical, with 12 of 30 testing positive for BYMV, 9 of 30 testing positive for CaYMV, and 29 of 30 testing positive for CaYSV. Representative outcomes for 20 samples taken from two varieties are shown in Figure 5A. The PCR products produced by multiplex and simplex reactions and visualized by agarose gel electrophoresis identified the same viruses in each sample. Samples that were negative for any of the viruses by multiplex PCR were also negative by simplex, indicating that the absence of detection is not due to poor performance of the multiplex method.

To demonstrate that this multiplex RT-PCR method is sensitive for detecting viral genomes in plant nucleic acid extracts (when using TNA rather than plasmids as starting material), we diluted 250, 25,
2.5, and $0.25 \mathrm{ng}$ of TNA from virus-infected plants in $500 \mathrm{ng}$ of TNA from healthy plants. TNA from a plant that was infected only with CaYMV (Fig. 5B, lanes 1 to 4), with CaYSV plus CaYMV (Fig. 5B, lanes 5 to 8), with all three viruses (Fig. 5B, lanes 9 to 12), or with CaYSV only (Fig. $5 \mathrm{~B}$, lanes 13 to 16 ) was used in the dilution series. The final concentration of cDNA in each reaction was $80 \mathrm{ng} / \mu \mathrm{l}$. The bands seen on a gel, representing CaYSV, CaYMV, and BYMV, were relatively abundant regardless of the mixed template dilutions (Fig. 5B).

To better understand the limit of detection of viral nucleic acids in TNA extracts, serial dilutions of four TNA were prepared in water. Plants belonging to Australia, Black Knight, and Tropical Sunrise (two burgundy- and one green-leaved varieties) were grown from rhizomes in the greenhouse, and TNA samples were prepared from each numbered plant. TNA was screened by multiplex RT-PCR and individuals were selected for this experiment that tested positive for various combinations of viruses. Specifically, Australia plant number 88 tested positive for CaYSV and CaYMV; Black Knight plant number 2 tested positive for CaYSV, CaYMV, and BYMV; Tropical Sunrise plant number 2 tested positive for CaYSV only; and Tropical Sunrise plant number 7 tested positive for CaYSV and BYMV (Fig. 5C). TNA was diluted 10 -fold from $500 \mathrm{ng} / \mu \mathrm{l}$ to $5 \mathrm{pg} / \mu \mathrm{l}$ and used in RT and PCR. CaYSV and CaYMV could be detected in as little as $5 \mathrm{pg}$ of TNA extracts (Fig. 5C). BYMV, however, was detected in $50 \mathrm{pg}$ of a Black Knight TNA extract and $5 \mathrm{pg}$ of a Tropical Sunrise TNA extract by multiplex PCR. Simplex PCR detected BYMV in as little as $50 \mathrm{pg}$ of Black Knight number 2 and Tropical Sunrise number 7 TNA (Fig. 5C). These data indicate that the multiplex PCR detection method is rather sensitive and can be used to reliably detect all three viruses in as little as $50 \mathrm{pg}$ of TNA, regardless of the plant variety.

The next question was whether all leaves of a plant test positive for a virus or whether the location of the sample is critical to obtain a positive test result. Samples were taken from four plants identified as Burning Ember numbers 5, 26, 37, and 40, which tested positive for CaYSV by multiplex RT-PCR. These plants had at least six leaves and were 3 months old. Leaves were numbered 1 through 6 , with 1 being closest to the soil surface and 6 being the youngest. Because the lower two leaves (numbered 1 and 2) were senescing, four

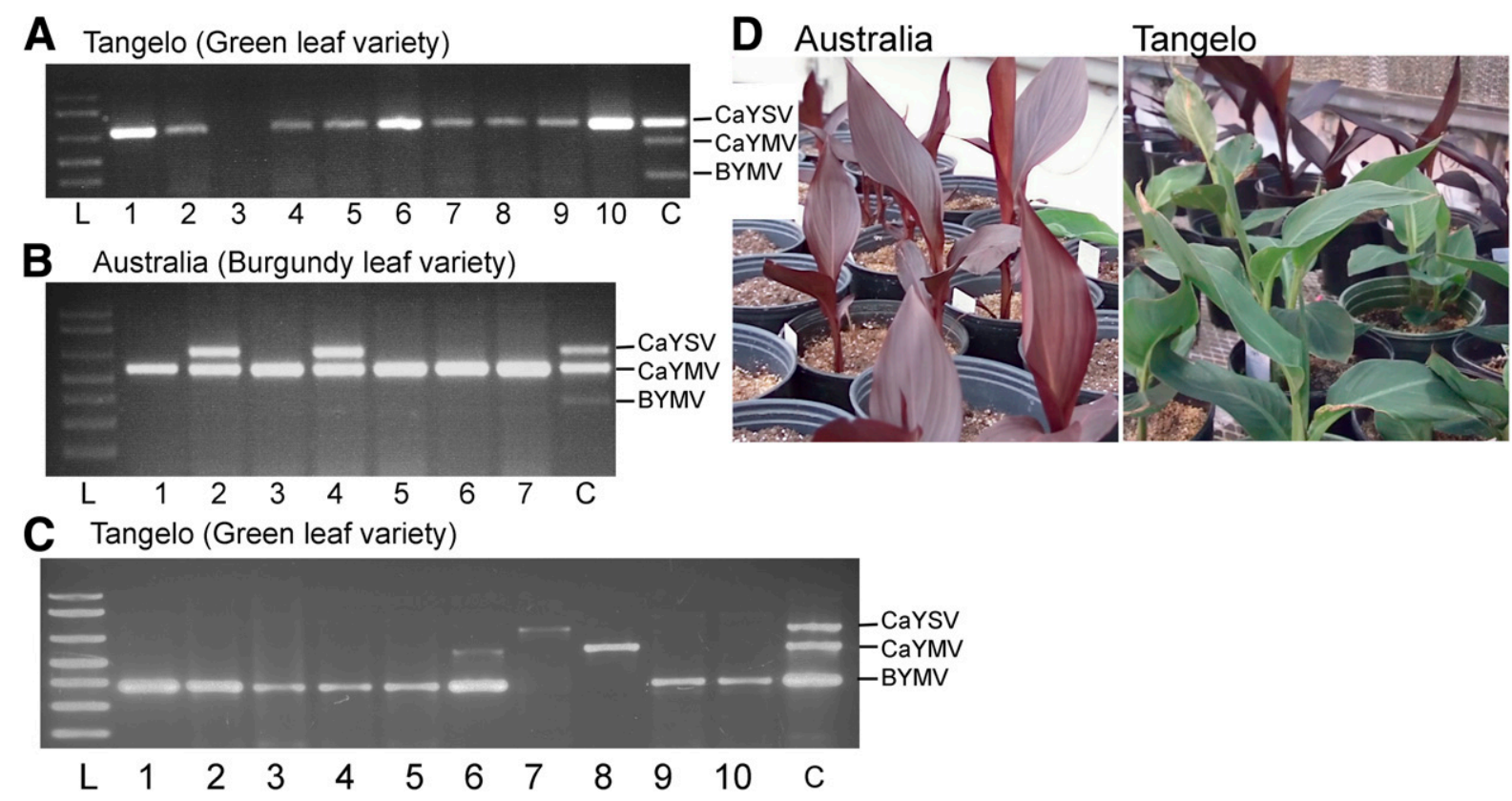

Fig. 4. Multiplex RT-PCR detection of viruses in canna leaf samples taken from greenhouse grown populations. A, B, and C, Numbered lanes show samples tested by multiplex reverse-transcription polymerase chain reaction (RT-PCR). "L" is the 1-kb Plus DNA ladder and "C" is the control multiplex RT-PCR carried out using mixture of pYSOK7672, pYM036P1, and pBYMV382 plasmids. Varieties sampled are identified above each panel. A, Samples tested positive only for Canna yellow streak virus (CaYSV). B, All samples tested positive for Canna yellow mottle virus (CaYMV) and two samples tested positive for CaYSV. C, Samples 1 to 6, 9 , and 10 tested positive for Bean yellow mosaic virus (BYMV). Samples in lanes 6 and 8 tested positive for CaYMV, and lane 7 tested positive for CaYSV. D, Representative images of 'Australia' and 'Tangelo' plants that were sampled from the greenhouse for these experiments. 
Burning Ember plants were selected and two leaf punches were taken from leaves 3 through 6 , with leaf 3 being closest to the soil surface and leaf 6 being the youngest fully expanded leaf. Leaves 3, 4, and 5 showed clear symptoms whereas leaf 6 was, at times, symptomless. Then, $500 \mathrm{ng}$ of TNA was used to prepare cDNA. PCR was carried out using a final concentration of cDNA of $80 \mathrm{ng} / \mu \mathrm{l}$. For each plant, CaYSV was detected in the most mature leaves 3,4 , and 5. In two plants, leaf 6 tested negative for virus infection. These data indicate that the youngest leaves are not as reliable for detecting virus as the fully expanded symptomatic leaves.

\section{Discussion}

For diagnostic detection of viruses, the bottleneck for many researchers is the reproducible recovery of high-quality nucleic acid preparations from a large number of samples that can be used for downstream applications. This report documents a highly reliable and sensitive multiplex RT-PCR that detects both positive-strand RNA virus and pararetrovirus genomes using a robust and automated TNA isolation procedure that is high yielding and captures a broad range of nucleotide species, including viral genomic nucleic acids and transcripts. Although most researchers cite visualization of the $28 \mathrm{~S}$ and 18S rRNA bands by agarose gel electrophoresis and a 28S/18S ratio of approximately 2.0 obtained by an Agilent Bioanalyzer as the best strategy for assessing RNA quality, in such a project that involves multiplex RT-PCR detection of viral genomes and transcripts, the automated RNA isolation method had to be designed to enrich for a broader range of RNA species (Kondo et al. 2013; Orjuela et al. 2013; Rakotomalala et al. 2013). In this study, agarose

A

Black Knight variety

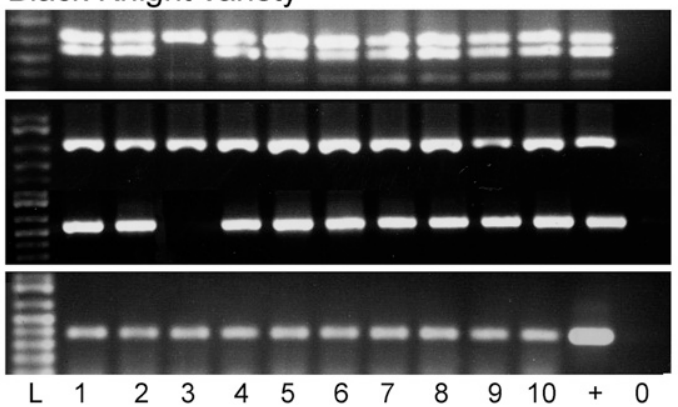

Tropical Sunrise variety

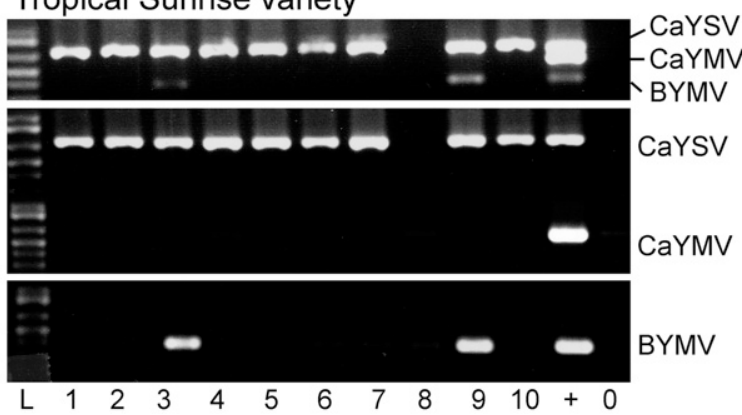

B

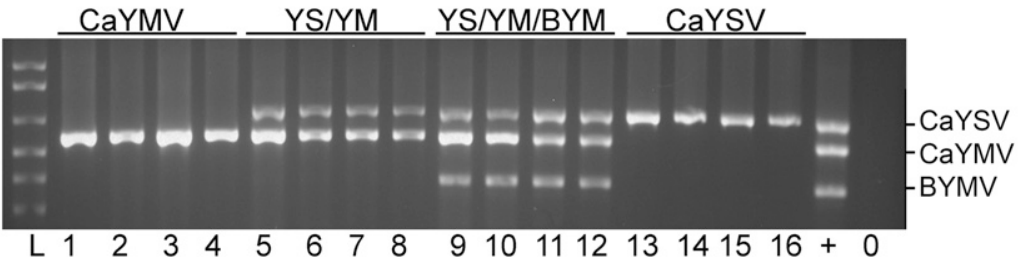

C
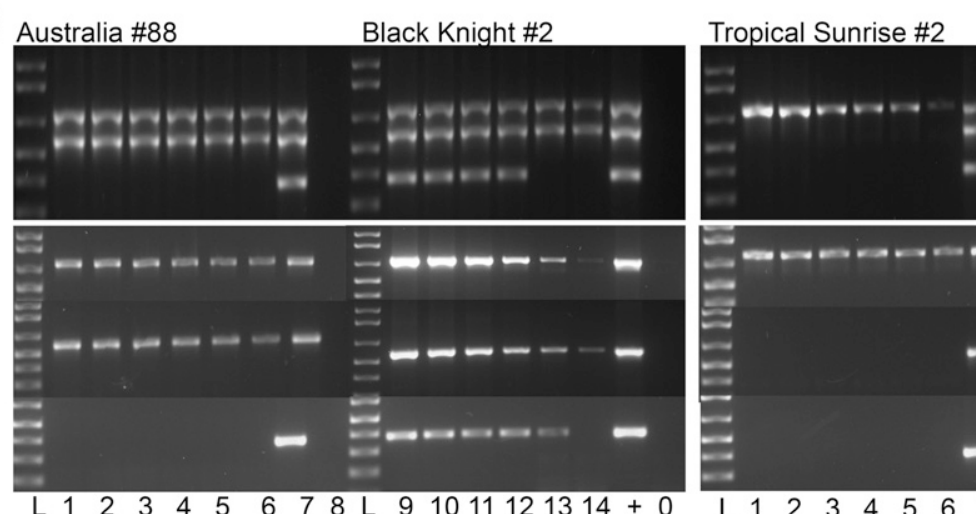

Tropical Sunrise \#7

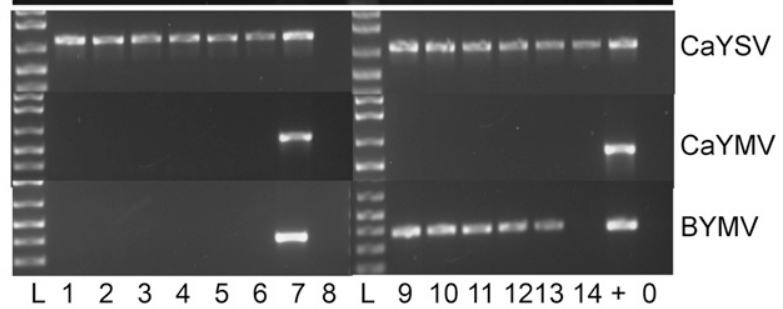

D

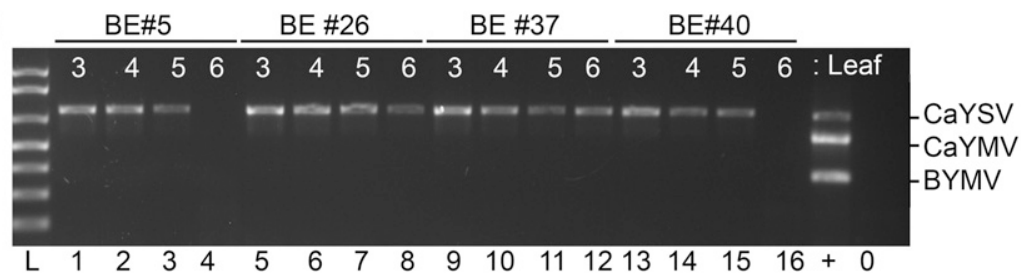

Fig. 5. Multiplex reverse-transcription polymerase chain reaction (RT-PCR) detection of viral nucleic acids in total nucleic acid (TNA) samples. TNA from plant variety identified at the top of each gel. PCR bands detecting Canna yellow streak virus (CaYSV), Canna yellow mottle virus (CaYMV), and Bean yellow mosaic virus (BYMV) are identified on the right. A, TNA was subjected to multiplex (top gel) and simplex (three next gels) PCR. B, Four TNA samples were diluted and used to carry out multiplex RT-PCR. Each series of four lanes corresponds to plants infected with CaYMV alone; CaYSV and CaYMV (YS/YM); CaYSV, CaYMV, and BYMV (YS/YM/BYM); or CaYSV alone, as indicated above the lanes. Lanes 1 to 4 contain PCR products produced using 250,25, 2.5, and $0.25 \mathrm{ng}$ of TNA, respectively, from virus-infected plants diluted in $500 \mathrm{ng}$ of TNA isolated from healthy plants. C, TNA was diluted in water and then used for RT-PCR. Lanes 1 to 6 contain PCR products produced using $500 \mathrm{ng}, 50 \mathrm{ng}, 5 \mathrm{ng}, 500 \mathrm{pg}, 50 \mathrm{pg}$, and $5 \mathrm{pg}$ of TNA, respectively. Lanes 9 to 14 were also produced using $500 \mathrm{ng}, 50 \mathrm{ng}, 5, \mathrm{ng}, 500 \mathrm{pg}, 50 \mathrm{pg}$, and $5 \mathrm{pg}$ of TNA, respectively. D, Four TNA samples taken from different leaves from four plants that were infected solely with CaYSV but were tested by multiplex RT-PCR. Individual plant code is provided at the top of the gel and the leaf number is provided at the top of each lane. 
gel electrophoresis showed that the TNA preparations obtained from canna leaves by modifying the automated Maxwell procedure contained an abundance of nucleic acid species, including plant genomic, organellar, and viral DNA as well as cytosolic, chloroplast, mitochondrial rRNA, and tRNA. The NanoDrop readings showed that an average 260/280 ratio of approximately 2.0 was achievable using the Maxwell LEV RNA extraction kit, regardless of whether the leaves came from green, burgundy, or variegated varieties. The Bioanalyzer data showed clear peaks representing a range of RNA species and RNA integrity number values that were greater than 7.0. Furthermore, small quantities of leaf tissue $(70 \mathrm{mg})$ produced sufficient yields of TNA that were satisfactory for downstream applications. Plant genomic DNA was also of a superior quality in the TNA extracts using the Maxwell kit compared with the Qiagen DNeasy Mini kit. However, we could not identify viral genomic DNA or RNA as abundant species on the gels in Figure 2B or by Bioanalyzer in Figure 2C.

In related work, researchers have used TRIZOL for nucleic acid extraction. Although the TRIZOL method can yield high-quality RNA, the homogenization step crucially determines the yield quality. Portillo et al. (2006) produced superior-quality RNA using a mortar and pestle compared with using glass bead homogenization when combined with TRIZOL. The TRIZOL method is a manual extraction method that starts with using a mortar and pestle for homogenization. For the purpose of automation, a mortar and pestle is not reasonable and precludes scaling up this procedure for handling hundreds or thousands of samples. The alternative semiautomated Maxwell-based method, demonstrated here, is designed for homogenization and nucleic acid extraction of multiple samples simultaneously using a BeadBug and Maxwell robot to yield a consistent quality of nucleic acids. Two additional advantages to using the Maxwell kit and robot rather than TRIZOL in this protocol are that (i) it does not involve phenol, chloroform, or isopropanol, which could contaminate the sample and alter the A260/280 ratios after extraction; and (ii) the quality of RNA is adequate for downstream applications.

The multiplex procedure was first optimized using plasmids diluted in water or healthy plant TNA. The primers used in this study were also reported for use in the simplex RT-PCR detection of BYMV, CaYMV, and CaYSV by several laboratories (BorrotoFernandez et al. 2008; Marino et al. 2008; Monger et al. 2007; Rajakaruna et al. 2014). We previously reported using the BYMV and CaYSV primers in simplex reaction with an annealing temperature of $50^{\circ} \mathrm{C}$, whereas the CaYMV primers were used with an annealing temperature of $60^{\circ} \mathrm{C}$ (Rajakaruna et al. 2014). When combined for the multiplex PCR, an annealing temperature between 50 and $55^{\circ} \mathrm{C}$ was identified by gradient PCR to be sufficient for detection of all three viruses. Therefore, we selected an annealing temperature of $52^{\circ} \mathrm{C}$ for efficient amplification of all three sequences from TNA. Similarly, the concentration of $\mathrm{MgCl}_{2}$ is known to significantly affect the relative efficiency and specificity of different primers. We tested various $\mathrm{MgCl}_{2}$ concentrations to improve simultaneous detection of all three viruses. Importantly, BYMV and CaYSV are potyviruses and the virus-specific primer sets amplify proximal regions of the respective virus coat protein genes. This study demonstrated that the BYMV- and CaYSV-specific primers recognized unique sequences in the respective viral genomes, can differentiate between BYMV and CaYSV plasmids, and can be combined for multiplex RT-PCR to differentiate between BYMV and CaYSV in infected leaf extracts. Furthermore, these primers were effectively combined for multiplex detection of viral cDNA at femtogram concentrations.

The second step was to assess the effectiveness of the multiplex RT-PCR assay for virus diagnosis when using TNA isolated from virus-infected plants. The initial experiments in Figure 4 demonstrated that similar results can be obtained by multiplex and simplex RT-PCR when using TNA as the template. With regard to sensitivity of the assay, the results in Figure 5 demonstrated that as little as $50 \mathrm{pg}$ of plant TNA, prepared using the modified Maxwell procedure, is sufficient to reliably detect all three viral nucleic acids by multiplex and simplex RT-PCR. Infected TNA samples were diluted in healthy
TNA extracts and in water and, in each case, the multiplex and simplex RT-PCR produced results that were highly sensitive and reproducible. Although we do not know the concentrations of viral genomic nucleic acids relative to the host nucleic acids in virusinfected TNA samples, the fact that as little as $50 \mathrm{pg}$ of virusinfected TNA is sufficient for a positive outcome points to the utility of this assay.

CaYMV is a badnavirus and its life cycle includes both DNA and RNA replicating intermediates. There is reason to suggest the possibility that CaYMV is similar to other badnaviruses and parts of its genome are integrated into the host genome. We do not yet know enough about the CaYMV infection cycle to know if there are endogenous and episomal forms of the genome. We also do not know the relative abundance of viral transcripts to genomic DNA. Therefore, the goal of the TNA extraction method is to capture a sufficient pool of both viral DNA and RNA that would enable the assay to detect the presence of CaYMV either through amplification of the viral DNA or viral transcripts. Further research is needed to determine the nature of the viral genome, and whether there are endogenous viral sequences that are either quiescent or active in the viral genome and could be responsible for producing disease. This current multiplex PCR assay is adequate and useful to demonstrate the presence of CaYMV in picogram quantities of plant TNA extracts and it is likely that, as we learn more about the nature of the CaYMV disease, further tests could be developed to differentiate endogenous and episomal viral DNA (Dahal et al. 2000; Gayral and Iskra-Caruana 2009; Gayral et al. 2008, 2010; Geering et al. 2005; Harper et al. 1999a).

This multiplex RT-PCR assay is an important practical advance in canna disease diagnostics. This first reported assay to detect potyviruses and pararetrovirus genomes by multiplex RT-PCR assays in canna plants represents a powerful new tool for monitoring diseases. The ability to carry out this work using small quantities of tissue and an automated nucleic acid extraction procedure is also new. For example, we reported that CaYSV and CaYMV sometimes cause symptomless infection or mild foliar symptoms in red-leaf varieties and, thus, escape field or greenhouse inspection. The ability to identify three viruses is critical for researchers to estimate the significance of these diseases for canna production. Because the CaYMV genome has not been reported and there are no commercial enzyme-linked immunosorbent assay kits available for CaYSV or CaYMV detection, this multiplex assay represents a useful advance that could be widely adopted by diagnostic laboratories.

\section{Acknowledgments}

This research was supported by the Oklahoma Center for Advancement of Science and Oklahoma Department of Agriculture. We thank the Oklahoma State University Core Facility; and undergraduate assistants H. Jones and A. Gimondo for prescreening plants selected for this study and managing the greenhouse.

\section{Literature Cited}

Borroto-Fernandez, E. G., Maghuly, F., Fellner, A., and Laimer, M. 2008 Determination of viral infections in an Austrian collection of Canna indica. J. Plant Dis. Prot. 115:102-107.

Chang, S., Puryear, J., and Cairney, J. 1993. A simple and efficient method for isolating RNA from pine trees. Plant Mol. Biol. Rep. 11:113-116.

Chauhan, R. P., Rajakaruna, P., and Verchot, J. 2015. Complete genome sequence of nine isolates of Canna yellow streak virus reveals its relationship to the Sugarcane mosaic virus (SCMV) subgroup of potyviruses. Arch. Virol. 160: 837-844.

Cooke, I. 2001. The Gardener's Guide to Growing Cannas. Timber Press, Portland, OR.

Dahal, G., Ortiz, R., Tenkouano, A., Hughes, J. D., Thottappilly, G., Vuylsteke, D., and Lockhart, B. E. L. 2000. Relationship between natural occurrence of banana streak badnavirus and symptom expression, relative concentration of viral antigen, and yield characteristics of some micropropagated Musa spp. Plant Pathol. 49:68-79.

Gambino, G., Perrone, I., and Gribaudo, I. 2008. A rapid and effective method for RNA extraction from different tissues of grapevine and other woody plants. Phytochem. Anal. 19:520-525.

Gayral, P., Blondin, L., Guidolin, O., Carreel, F., Hippolyte, I., Perrier, X., and Iskra-Caruana, M. L. 2010. Evolution of endogenous sequences of banana streak virus: What can we learn from banana (Musa sp.) evolution? J. Virol 84:7346-7359. 
Gayral, P., and Iskra-Caruana, M. L. 2009. Phylogeny of Banana Streak Virus reveals recent and repetitive endogenization in the genome of its banana host (Musa sp.). J. Mol. Evol. 69:65-80.

Gayral, P., Noa-Carrazana, J. C., Lescot, M., Lheureux, F., Lockhart, B. E., Matsumoto, T., Piffanelli, P., and Iskra-Caruana, M. L. 2008. A single Banana streak virus integration event in the banana genome as the origin of infectious endogenous pararetrovirus. J. Virol. 82:6697-6710.

Ge, B., Li, Q., Liu, G., Lu, M., Li, S., and Wang, H. 2013. Simultaneous detection and identification of four viruses infecting pepino by multiplex RT-PCR. Arch. Virol. 158:1181-1187.

Geering, A. D., Olszewski, N. E., Harper, G., Lockhart, B. E., Hull, R., and Thomas, J. E. 2005. Banana contains a diverse array of endogenous badnaviruses. J. Gen. Virol. 86:511-520.

Gillet, F. X., Cattoni, D. I., Petiot-Becard, S., Delalande, F., Poignavent, V., Brizard, J. P., Bessin, Y., Dorsselaer, A. V., Declerck, N., SanglierCianferani, S., Brugidou, C., and Vignols, F. 2013. The RYMV-encoded viral suppressor of RNA silencing P1 is a zinc-binding protein with redoxdependent flexibility. J. Mol. Biol. 425:2423-2435.

Harper, G., Dahal, G., Thottappilly, G., and Hull, R. 1999a. Detection of episomal banana streak badnavirus by IC-PCR. J. Virol. Methods 79:1-8.

Harper, G., Osuji, J. O., Heslop-Harrison, J. S., and Hull, R. 1999b. Integration of banana streak badnavirus into the Musa genome: Molecular and cytogenetic evidence. Virology 255:207-213.

Kalinowska, E., Chodorska, M., Paduch-Cichal, E., and Mroczkowska, K. 2012. An improved method for RNA isolation from plants using commercial extraction kits. Acta Biochim. Pol. 59:391-393.

Kondo, H., Hirano, S., Chiba, S., Andika, I. B., Hirai, M., Maeda, T., and Tamada, T. 2013. Characterization of burdock mottle virus, a novel member of the genus Benyvirus, and the identification of benyvirus-related sequences in the plant and insect genomes. Virus Res. 177:75-86.

Li, R., Mock, R., Huang, Q., Abad, J., Hartung, J., and Kinard, G. 2008. A reliable and inexpensive method of nucleic acid extraction for the PCR-based detection of diverse plant pathogens. J. Virol. Methods 154:48-55.

Lockhart, B. 1988. Occurrence of Canna yellow mottle virus in North America. Acta Hortic. 234:69-72.
Maas-Van De Kamer, H. M. V., and Maas, P. J. M. 2008. The Cannaceae of the world. Blumea 53:247-318.

Marino, M. T., Ragozzino, E., Lockhart, B. E. L., Miglino, R., and Alioto, D. 2008 First report of Canna yellow mottle virus (CaYMV) in Italy and in the Netherlands. Plant Pathol. 57:394.

Monger, W. A., Adams, I. P., Glover, R. H., and Barrett, B. 2010. The complete genome sequence of Canna yellow streak virus. Arch. Virol. 155: 1515-1518.

Monger, W. A., Harju, V., Skelton, A., Seal, S. E., and Mumford, R. A. 2007. Canna yellow streak virus: A new potyvirus associated with severe streaking symptoms in canna. Arch. Virol. 152:1527-1530.

Orjuela, J., Deless, E. F., Kolade, O., Cheron, S., Ghesquiere, A., and Albar, L. 2013. A recessive resistance to Rice yellow mottle virus is associated with a rice Homolog of the CPR5 gene, a regulator of active defense mechanisms. Mol. Plant-Microbe Interact. 26:1455-1463.

Periasamy, M., Niazi, F. R., and Malathi, V. G. 2006. Multiplex RT-PCR, a novel technique for the simultaneous detection of the DNA and RNA viruses causing rice tungro disease. J. Virol. Methods 134:230-236.

Pervaiz, Z. H., Turi, N. A., Khaliq, I., Rabbani, M. A., and Malik, S. A. 2011. Methodology: A modified method for high-quality DNA extraction for molecular analysis in cereal plants. Genet. Mol. Res. 10:1669-1673.

Portillo, M., Fenoll, C., and Escobar, C. 2006. Evaluation of different RNA extraction methods for small quantities of plant tissue: Combined effects of reagent type and homogenization procedure on RNA quality, integrity and yield. Physiol. Plant. 128:1-7.

Rajakaruna, P., Shafiekhani, M., Kim, T., Payton, M., Chauhan, R., and Verchot, J 2014. Production of discernable disease phenotypes in canna by five plant viruses belonging to the genera Potyvirus, Cucumovirus, and Badnavirus. Plant Pathol. J. 63:821-830.

Rakotomalala, M., Pinel-Galzi, A., Mpunami, A., Randrianasolo, A., Ramavovololona, P., Rabenantoandro, Y., and Fargette, D. 2013. Rice yellow mottle virus in Madagascar and in the Zanzibar Archipelago; island systems and evolutionary time scale to study virus emergence. Virus Res. 171:71-79.

Slater, A. 1988. Extraction of RNA from plants. Methods Mol. Biol. 4: 437-446. 